\title{
MANY NESTS ON ONE SMALL LOT
}

\section{MRS. JEAN BANCROFT, 264 Campbell Street, Winnipeg, Manitoba R3N 1B5}

During summer 1977, I observed and recorded events at 11 different nests, of which 10 were successful, on a well treed 16-square-metre lot. The property is located in front of a gasoline service station about 5 kilometres south of Winnipeg Beach on the south shore of Lake Winnipeg. During the period from May 27 to August 1 there were nine different species of birds in various nesting stages (Table 1).

I was interested and excited by the number of species nesting on the one small area during the same time.

With the exception of a large spruce and a dead ash, all the trees were Manitoba maples. Virginia creeper grew wild over one side of a fence and made a thick cover over some dead shrubs. Across the road from this lot, the lake front habitat had been completely denuded by a severe infestation of forest tent caterpillars, but for some reason the trees on the lot remained in full foliage. This may have been one of the reasons for the large number of nesting birds.

As regards the Rusty Blackbird although I am an amateur birder I am

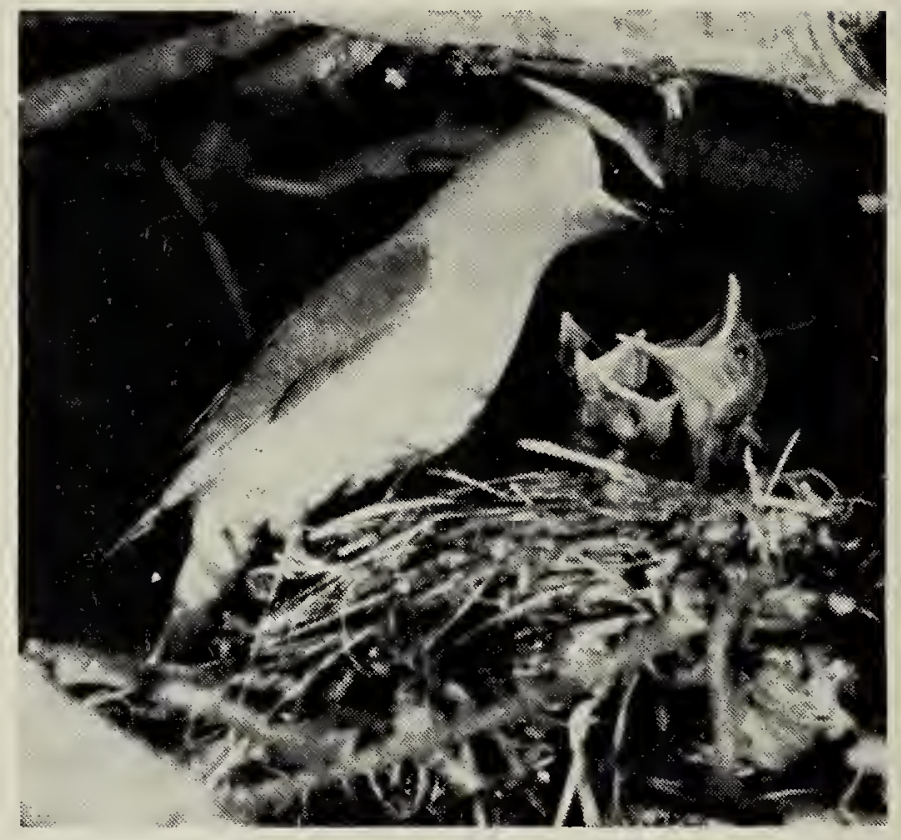

Cedar Waxwing nest

Larry A. Morgotch

well acquainted with the Common Grackle. I identified the Rusty Blackbird by the yellow eyes of the incubating female, a character that separates it from the Brewer's Blackbird. I have since been informed that there are no previous summer records for this species at this latitude in Manitoba. It is unfortunate that I did not let others know about this nesting in time to have the species verified. Let other amateurs take heed!

Table 1. ACTIVE NESTS AT THE SAME TIME ON A 16-SQUARE-METER LOT.

\begin{tabular}{llll}
\hline Species & Number of nests & Height (metres) & Nesting completed \\
\hline American Robin & $2^{*}$ & 6,1 & June 24 , July 15 \\
Northern Oriole & 1 & 3 & June 24 \\
Cedar Waxwing & 1 & 6 & July 2 \\
Rusty Blackbird & 1 & $61 / 2$ & June 27 \\
Gray Catbird & 1 & $1 \frac{11 / 2}{}$ & August 1 \\
Tree Swallow & 1 & 4 & July 10 \\
House Wren & 1 & 2 & July 27 \\
Yellow Warbler & 2 & $4^{* *}, 3 \frac{1 / 2}{}$ & July 21 \\
Mourning Dove & 1 & 5 & July 21
\end{tabular}

${ }^{\star}$ Opposite sides of property.

${ }^{*}$ Nest found destroyed, headless young on ground. Second nest believed to be renesting by same pair. 